\title{
Simultaneous Determination of Levocetirizine and Pseudoephedrine in Dog Plasma by Liquid Chromatography-Mass Spectrometry in the Presence of Dextrocetirizine
}

\author{
Jae Kuk Ryu ${ }^{\mathrm{a}}$, Sun Dong Yoo ${ }^{\mathrm{b}}$ \\ ${ }^{a}$ Department of Pharmaceutical Engineering, Sangji University, Wonju-si, 220-702, Korea. \\ ${ }^{\mathrm{b}}$ School of Pharmacy, Sungkyunkwan University, Suwon 440-746, Republic of Korea.
}

Received, May 6, 2012; Revised, August 9, 2012; Accepted, September 14, 2012; Published, September 17, 2012.

\begin{abstract}
Purpose. This study describes the development of a rapid and sensitive LC-ESI-MS assay for simultaneous enantioselective determination of levocetirizine and pseudoephedrine in dog plasma in the presence of dextrocetirizine. Methods. Separations were achieved on an Ultron ES-OVM chiral column using the mobile phase consisting of $10 \mathrm{mM}$ aqueous $\mathrm{NH}_{4} \mathrm{OAc}(\mathrm{pH} 6.6)$ and acetonitrile $(9: 1 \mathrm{v} / \mathrm{v})$. Results. The retention times of pseudoephedrine, dextrocetirizine, levocetirizine and diazepam (internal standard) were 5.2, 8.3, 9.6 and $11.6 \mathrm{~min}$, respectively, and the total run time was less than $15 \mathrm{~min}$. The assay was validated to demonstrate the linearity, accuracy and precision, recovery and stability. The calibration curves were linear over the concentration range from $1-200 \mathrm{ng} / \mathrm{mL}$ for levocetirizine and from $5-1000 \mathrm{ng} / \mathrm{mL}$ for pseudoephedrine. Conclusions. The developed assay was successfully applied to a pharmacokinetic study after oral administration of the racemic cetirizine $(0.5 \mathrm{mg} / \mathrm{kg}$, or $0.25 \mathrm{mg} / \mathrm{kg}$ as levocetirizine) and pseudoephedrine $(12 \mathrm{mg} / \mathrm{kg})$ in the dog.
\end{abstract}

This article is open to POST-PUBLICATI ON REVIEW. Registered readers (see "For Readers") may comment by clicking on ABSTRACT on the issue's contents page.

\section{INTRODUCTION}

Cetirizine, $( \pm)$ - [ 2 - ( 4 - [ ( 4 - chlorophenyl ) phenylmethyl]-1-piperazinyl) ethoxy] acetic acid, is an orally active histamine $\mathrm{H}_{1}$-receptor antagonist used for the treatment of seasonal allergic rhinitis, perennial allergic rhinitis and chronic idiopathic urticaria. It is a racemate with the $\mathrm{R}$ enantiomer (levocetirizine) (Figure 1) being pharmacologically active, exhibiting approximately 30 -fold higher affinity to human histamine $\mathrm{H}_{1}$-receptors than its antipode, dextrocetirizine (1). Pseudoephedrine, [1S, 2S]-2methylamino-1-phenylpropan-1-ol] (Figure 1), is an alpha-adrenergic agonist used as a nasal decongestant in patients with allergic rhinitis and in acute rhinitis in patients with upper-respiratory infections. It is a stereoisomer of ephedrine and is less potent than ephedrine in producing tachycardia and CNS stimulation. Combination therapy involving levocetirizine and pseudoephedrine may effectively reduce the nasal congestion due to allergic rhinitis. In developing and evaluating a sustained release oral dosage formulation containing levocetirizine and pseudoephedrine, it may be desirable to use a rapid and sensitive assay method that can simultaneously measure plasma concentrations of both drugs in the presence of dextrocetirizine.
HPLC (2-3) and subcritical fluid chromatography (4) with UV detection methods are available for the determination of levocetirizine. These methods generally have poor assay sensitivity and require long analytical run times. Recently, a LC-MS/MS assay has been reported for the determination of plasma levels of levocetirizine (5). This assay, however, requires the time-consuming two-step sample extraction procedures and the normal phase liquid chromatographic separation using organic solvents that are toxic, expensive and difficult to remove eco-friendly. A number of assay methods have been reported for the analysis of pseudoephedrine, including HPLC (6-8), GC (910) and LC-MS/MS (11-13). The HPLC assays involve either time-consuming double liquidliquid extraction $(6,8)$ or solid phase extraction adapted to an automated column switching method for online sample preparation (7). The sample preparation procedures of the GC assay needs laborious derivatization reactions (9-10). The LC-MS/MS assays are achiral methods (1113) and cannot be used for the simultaneous enantioselective determination of levocetirizine and pseudoephedrine.

Corresponding Author: Sun Dong Yoo, Ph.D. School of Pharmacy, Sungkyunkwan University, Suwon, Republic of Korea, E-mail:sdyoo@skku.ac.kr 


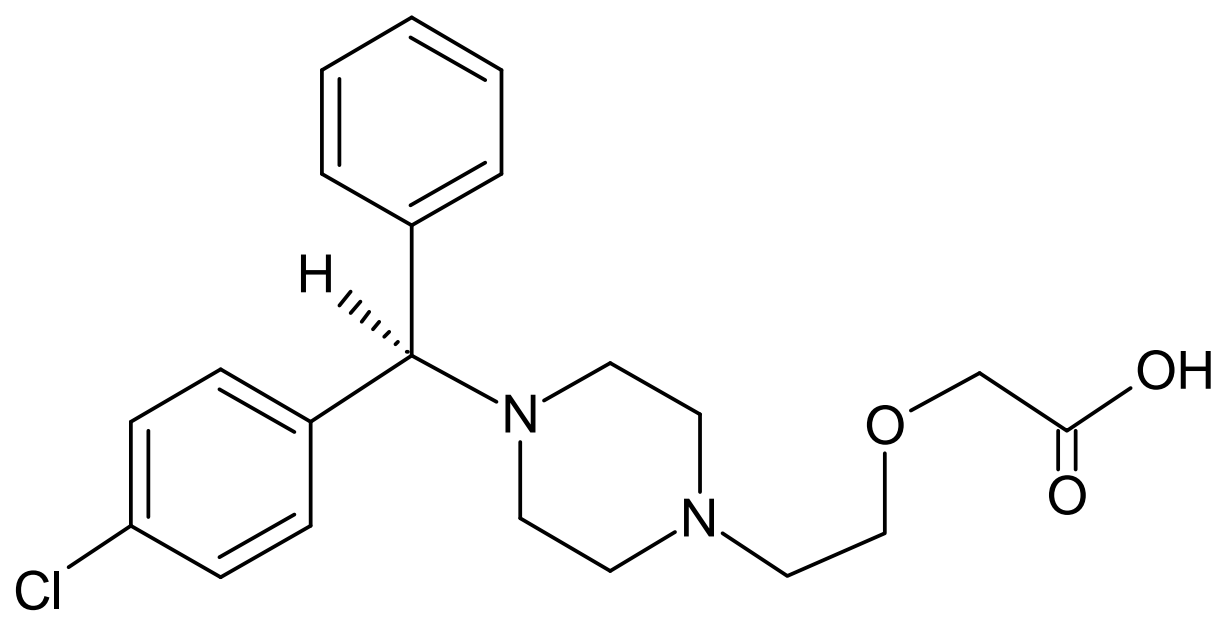

Levocetirizine

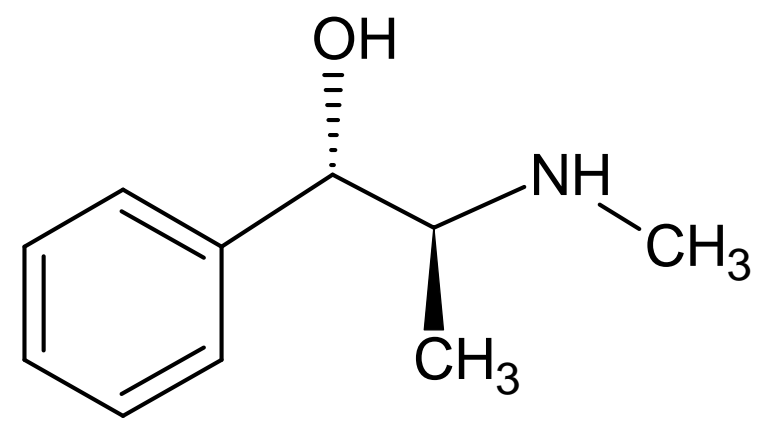

\section{Pseudoephedrine}

Figure 1. Chemical structures of levocetirizine and pseudoephedrine.

As pseudoephedrine is a diastereomer of ephedrine, the $\mathrm{m} / \mathrm{z}$ ratios of parent and daughter ions in the LC-MS/MS methods (11-13) are identical with each other and the physicochemical properties are very similar. The retentions of pseudoephedrine in the chromatographic column in those methods (11-13) might be too short to separate the drug from a diastereomer, ephedrine and other endogeneous or exogeneous substances with identical molecular formula and similar chemical structures to the drug. To our knowledge, no assay method is available for the simultaneous determination of levocetirizine and pseudoephedrine in biological fluids.

This study for the first time reports the development of a novel reversed-phase LC-MS assay for the simultaneous determination of levocetirizine and pseudoephedrine in dog plasma in the presence of dextrocetirizine. The developed assay was successfully applied to a pharmacokinetic study after oral administration of racemic cetirizine $(0.5 \mathrm{mg} / \mathrm{kg}$, or $0.25 \mathrm{mg} / \mathrm{kg}$ as levocetirizine) and pseudoephedrine (12 $\mathrm{mg} / \mathrm{kg})$ in the dog. It was assumed that $50 \%$ of the racemic cetirizine was levocetirizine and the other $50 \%$ was dextrocetirizine.

\section{EXPERIMENTAL}

\section{Chemicals}

Levocetirizine dihydrochloride, cetirizine dihydrochloride and pseudoephedrine hydrochloride, were provided by Hanmi Pharmaceutical Co. (Seoul, Korea). Diazepam and 
ammonium acetate $\left(\mathrm{NH}_{4} \mathrm{OAc}\right)$ were obtained from Sigma Chemical Co. (St. Louis, Mo, USA). Acetonitrile and methanol were purchased from J.T. Baker (Phillipsburg, NJ, USA). Ethyl acetate was obtained from Merck (Darmstadt, Germany). Water used in this study was purified by the MilliQ-Grade water system (Millipore, Bedford, MA, USA).

\section{Instrumentation}

The HPLC was performed with a Waters Alliance HT 2795 Chromatography System (Waters Corp., Milford, MA, USA). Chromatographic separations were achieved on an Ultron ES-OVM chiral analytical column $(150 \times 4.6 \mathrm{~mm}, 5 \mu \mathrm{m}$, Shinhwa Chemical, Kyoto, Japan) coupled with a guard column containing the identical packing material to that of the analytical column. The mobile phase was a mixture of $10 \mathrm{mM}$ aqueous $\mathrm{NH}_{4} \mathrm{OAc}(\mathrm{pH} 6.6)$ and acetonitrile $(9: 1 \mathrm{v} / \mathrm{v})$. The flow rate of the mobile phase was set at 1.0 $\mathrm{mL} / \mathrm{min}$ (flow was split $20 \%$ to the source, and $80 \%$ to waste) and the column temperature was held at $30^{\circ} \mathrm{C}$.

The HPLC system was coupled to a Waters ZQ 4000 mass spectrometer (Waters Corp., Milford, MA, USA) equipped with electrospray ionization (ESI) source. The ESI source was operated in a positive mode. The source temperature $\left(150^{\circ} \mathrm{C}\right)$, de-solvation temperature $\left(200^{\circ} \mathrm{C}\right)$, cone voltage $(3.00 \mathrm{kV})$ and capillary voltage $(16 \mathrm{~V})$ were optimized. A single ion recording (SIR) was observed at $\mathrm{m} / \mathrm{z} 389.1$ for levocetirizine. Dextrocetirizine was also detected at $\mathrm{m} / \mathrm{z} 389.1$ but the retention time was different from that of levocetirizine. SIR was observed at $\mathrm{m} / \mathrm{z} 166.1$ and 285.0 for pseudoephedrine and diazepam, respectively. The system control and data acquisition was performed using MassLynx 3.5 (Waters Corp., Milford, MA, USA).

\section{Preparation of stock and standard solutions and QC samples}

The stock solutions levocetirizine $(100 \mu \mathrm{g} / \mathrm{mL})$, pseudoephedrine $(100 \mu \mathrm{g} / \mathrm{mL})$ and diazepam (internal standard, $100 \mu \mathrm{g} / \mathrm{mL}$ ) were prepared by separately dissolving $23.8 \mathrm{mg}$ of cetirizine dihydrochloride, $12.2 \mathrm{mg}$ of pseudoephedrine hydrochloride and $10.0 \mathrm{mg}$ diazepam in $100 \mathrm{~mL}$ of water, respectively, and stored at $-80^{\circ} \mathrm{C}$. The racemic cetirizine rather than levocetirizine $(\mathrm{R}$ enantiomer) was used to ensure the separation of dextrocetirizine (S enantiomer) and levocetirizine. The standard working solutions were prepared by serial dilution with $60 \%$ acetonitrile, yielding concentrations of $10,20,50,100,200,500,1000$ and $2000 \mathrm{ng} / \mathrm{mL}$ for levocetirizine and 50, 100, $200,500,1000,2000,5000$ and $10000 \mathrm{ng} / \mathrm{mL}$ for pseudoephedrine. The stock solution of diazepam was diluted with $60 \%$ acetonitrile to provide the internal standard working solution (concentration, $2000 \mathrm{ng} / \mathrm{mL}$ ). Quality control (QC) samples of levocetirizine were prepared by spiking the standard working solutions to blank dog plasma to provide low $(3 \mathrm{ng} / \mathrm{mL})$, medium $(100 \mathrm{ng} / \mathrm{mL})$ and high $(160 \mathrm{ng} / \mathrm{mL})$ concentrations and LLOQ (1 $\mathrm{ng} / \mathrm{mL}$ ). Similarly, QC samples of pseudoephedrine were prepared by spiking the standard working solutions to blank dog plasma to provide to provide low $(15 \mathrm{ng} / \mathrm{mL})$, medium (500 $\mathrm{ng} / \mathrm{mL})$ and high $(800 \mathrm{ng} / \mathrm{mL})$ concentrations and LLOQ $(5 \mathrm{ng} / \mathrm{mL})$. The prepared QC samples were stored at $-20^{\circ} \mathrm{C}$ until analysis.

\section{Sample preparation}

Frozen dog plasma samples were thawed at room temperature. For sample extraction, $50 \mu \mathrm{L}$ of the internal standard solution $(2000 \mathrm{ng} / \mathrm{mL})$ and 0.5 $\mathrm{mL}$ each of water and acetonitrile were added to $0.5 \mathrm{~mL}$ of dog plasma. After vortex-mixing for 1 min, $3 \mathrm{~mL}$ of ethyl acetate was added, and the mixture was vortex-mixed for $5 \mathrm{~min}$ and centrifuged for $3 \mathrm{~min}$ at $12,000 \mathrm{~g}$. The supernatant $(2.5 \mathrm{~mL})$ was transferred to a clean glass tube and evaporated to dryness under nitrogen at $40^{\circ} \mathrm{C}$. The residue was dissolved in $150 \mu \mathrm{L}$ of the mobile phase and centrifuged for $3 \mathrm{~min}$ at $12,000 \mathrm{~g}$. The supernatant were transferred to an auto-sampler vial, and a portion $(50 \mu \mathrm{L})$ was injected into the chromatograph.

\section{Calibration curves}

Calibration curves were prepared by spiking blank dog plasma with levocetirizine standard working solutions at concentrations of 1, 2, 5, 10, 20, 50, 100 and $200 \mathrm{ng} / \mathrm{mL}$ and with pseudoephedrine standard working solutions at concentrations of 5 , $10,20,50,100,200,500$ and $1000 \mathrm{ng} / \mathrm{mL}$. The calibration curves were constructed by the weighted regression method $(1 / \mathrm{x})$ of the peak area ratios of drug-to-internal standard vs. actual concentrations. The calibration curves were prepared on a daily basis. To determine the between-run variability of the slopes and intercepts, calibration curves were constructed on three different days.

\section{Linearity}

The weighted regression method $(1 / \mathrm{x})$ which takes into account the peak area ratios as a function of the theoretical concentrations was applied to each standard curve $[y=a x+b$, where 
$x=$ concentration $(\mathrm{ng} / \mathrm{mL}), y=$ peak area ratio, $a=$ slope and $b=$ intercept]. The equation parameters (slope and intercept) of each standard curve were used to determine concentration values for unknown samples. Concentrations were backcalculated and compared with the nominal concentrations, and the relative concentration residuals (RCRs) were calculated (14).

\section{Specificity, precision and accuracy}

The assay specificity was investigated by screening six different batches of blank dog plasma to check whether endogenous components co-eluted with levocetirizine, pseudoephedrine and diazepam. The precision and accuracy were assessed from the results of the QC samples. Each QC sample with four concentration levels was analyzed consecutively six times within one day $(n=6)$ to determine the within-run precision and accuracy, and once a day for six successive days $(n=6)$ to determine the between-run precision and accuracy. The precision was expressed as the coefficient of variance of each concentration, and the accuracy was expressed as the percentage of mean calculated vs. theoretical concentrations.

\section{Determination of quantification limits}

The lower limit of quantification (LLOQ) was defined as the lowest plasma concentration that can be measured with acceptable accuracy and precision. The measured concentration of the proposed LLOQ should lie between 80 and $120 \%$ of its theoretical concentration, and the relative standard deviation should be less than $20 \%$ (10). The LLOQ was derived from measurements in the low concentration range and determined based on the signal-to-noise $(\mathrm{S} / \mathrm{N})$ ratio. A concentration of a $\mathrm{S} / \mathrm{N}$ ratio $>10$, with precision of $<20 \%$ and accuracy between 80 and $120 \%$ was used as the LLOQ, which was the lowest concentration point in the calibration curve.

\section{Extraction efficiency and matrix effects}

The extraction efficiency was determined three times at the QC concentration levels for levocetirizine and pseudoephedrine and at the concentration level used during the assay for the internal standard $(2000 \mathrm{ng} / \mathrm{mL})$. The peak areas of analytes extracted from plasma samples were compared to those obtained from direct injections of the standard solutions prepared in the mobile phase at equivalent concentrations without extraction. Matrix effects were assessed qualitatively by post-column infusion experiments in order to identify chromatographic regions most likely to experience ion suppression or enhancement of ESI mass spectrometry response in the presence of endogenous plasma interferences $(5,15)$.

\section{Stability study}

The stability of stock solutions was examined at $80^{\circ} \mathrm{C}$ over a period of 3 months, while that of working solutions containing both levocetirizine $(50 \mathrm{ng} / \mathrm{mL})$ and pseudoephedrine $(200 \mathrm{ng} / \mathrm{mL})$ was assessed immediately after preparation and a week after storage at room temperature and at $4^{\circ} \mathrm{C}$. The short-term stability was tested with QC samples at concentrations of 3 and $160 \mathrm{ng} / \mathrm{mL}$ for levocetirizine and 15 and $800 \mathrm{ng} / \mathrm{mL}$ for pseudoephedrine in plasma over $24 \mathrm{~h}$ at room temperature and at $4^{\circ} \mathrm{C}$. The stability of the drug in frozen samples $\left(-80^{\circ} \mathrm{C}\right)$ was determined by periodic analysis over 3 months. The freeze thaw stability of the drug at $-80^{\circ} \mathrm{C}$ was confirmed after three freeze thaw cycles on consecutive days. The drug was considered stable if the assay values were within the acceptable limits of accuracy and precision $(<15 \%)(5)$.

\section{Pharmacokinetic study}

The validated assay was applied to a pharmacokinetic study in the dog after oral coadministration of the racemic cetirizine $(0.5$ $\mathrm{mg} / \mathrm{kg}$, or $0.25 \mathrm{mg} / \mathrm{kg}$ as levocetirizine) and pseudoephedrine $(12 \mathrm{mg} / \mathrm{kg})$. Male beagle dogs (body weight, 9-11 kg) were used in the study. The animals were housed individually with free access to Golden-pet dog diet (Agribrands, Seoul, Korea) and water. The animals were maintained at a temperature of $23 \pm 3^{\circ} \mathrm{C}$ with a $12 \mathrm{~h}$ light-dark cycle and a relative humidity of $50 \pm 20 \%$. The experiment was carried out after overnight fasting with free access to water. All procedures used in this study were performed in accordance with the Guide for the Care and Use of Laboratory animals, and the work was approved by the Ethics Committee of the Faculty. After drug administration, approximately $2 \mathrm{~mL}$ of blood was obtained from the foreleg vein immediately before and $0.33,0.67,1,1.5,2,3,4,6,8,12$ and $24 \mathrm{~h}$ after administration. Blood samples were centrifuged immediately at $4^{\circ} \mathrm{C}$ and the harvested plasma samples were stored at $-80^{\circ} \mathrm{C}$ until analysis. Plasma concentration-time data were analyzed by the non-compartmental method using the nonlinear least-squares regression program WinNonlin (Pharsight, Mountain View, CA, USA). 


\section{RESULTS}

\section{Assay specificity}

Typical chromatograms of the extracted blank plasma spiked with levocetirizine, dextrocetirizine, pseudoephedrine and diazepam are shown in Figure 2. Chromatograms of the extracted plasma sample obtained at $90 \mathrm{~min}$ after drug administration are shown in Figure 3. The retention times of pseudoephedrine, dextrocetirizine, levocetirizine and diazepam were approximately 5.2, 8.3, 9.6 and $11.6 \mathrm{~min}$, respectively. No endogenous or extraneous peaks were observed interfering with the assay.

\section{Linearity}

The calibration curve parameters demonstrate the linear relationship between the peak area ratios vs. the internal standard over the concentration range from $1-200 \mathrm{ng} / \mathrm{mL}$ for levocetirizine and 5 $1000 \mathrm{ng} / \mathrm{mL}$ for pseudoephedrine. Linearity was confirmed by the coefficient of determination $\left(r^{2}\right)$ for both levocetirizine $\left(r^{2}>0.999\right)$ and pseudoephedrine $\left(r^{2}>0.994\right)$.

\section{Assay accuracy and precision}

The within- and between-run accuracy and precisions were assessed from the results of the QC samples (Table 1). The within-run precision showed R.S.D.s of $6.6-15.5 \%$ for levocetirizine and $6.5-16.0 \%$ for pseudoephedrine. The between-run R.S.D.s varied from $5.9-15.0 \%$ (LLOQ) for levocetirizine and $7.7-17.9 \%$ (LLOQ) for pseudoephedrine. The accuracy ranged from 97.2 to $117.8 \%$ for levocetirizine and $97.3-117.2 \%$ (LLOQ) for pseudoephedrine.

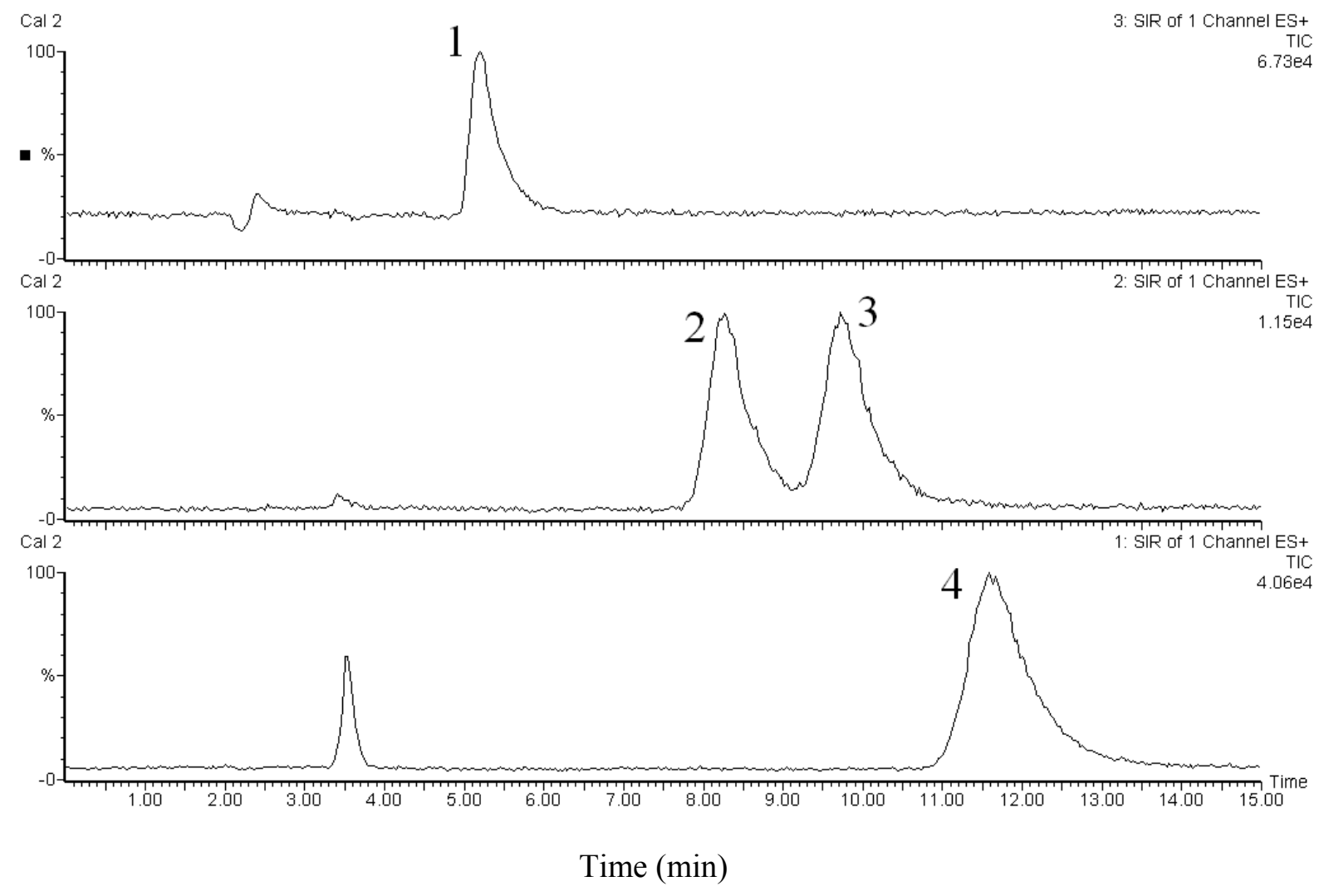

Figure 2. Chromatograms of blank plasma spiked with $200 \mathrm{ng} / \mathrm{mL}$ of cetirizine (or $100 \mathrm{ng} / \mathrm{mL}$ of dextrocetirizine and $100 \mathrm{ng} / \mathrm{mL}$ of levocetirizine) and $500 \mathrm{ng} / \mathrm{mL}$ of pseudoephedrine. Peaks 1, 2, 3 and 4 are pseudoephedrine, dextrocetirizine, levocetirizine and diazepam (internal standard), respectively. Their retention times were approximately 5.2, 8.3, 9.6 and $11.6 \mathrm{~min}$, respectively. 


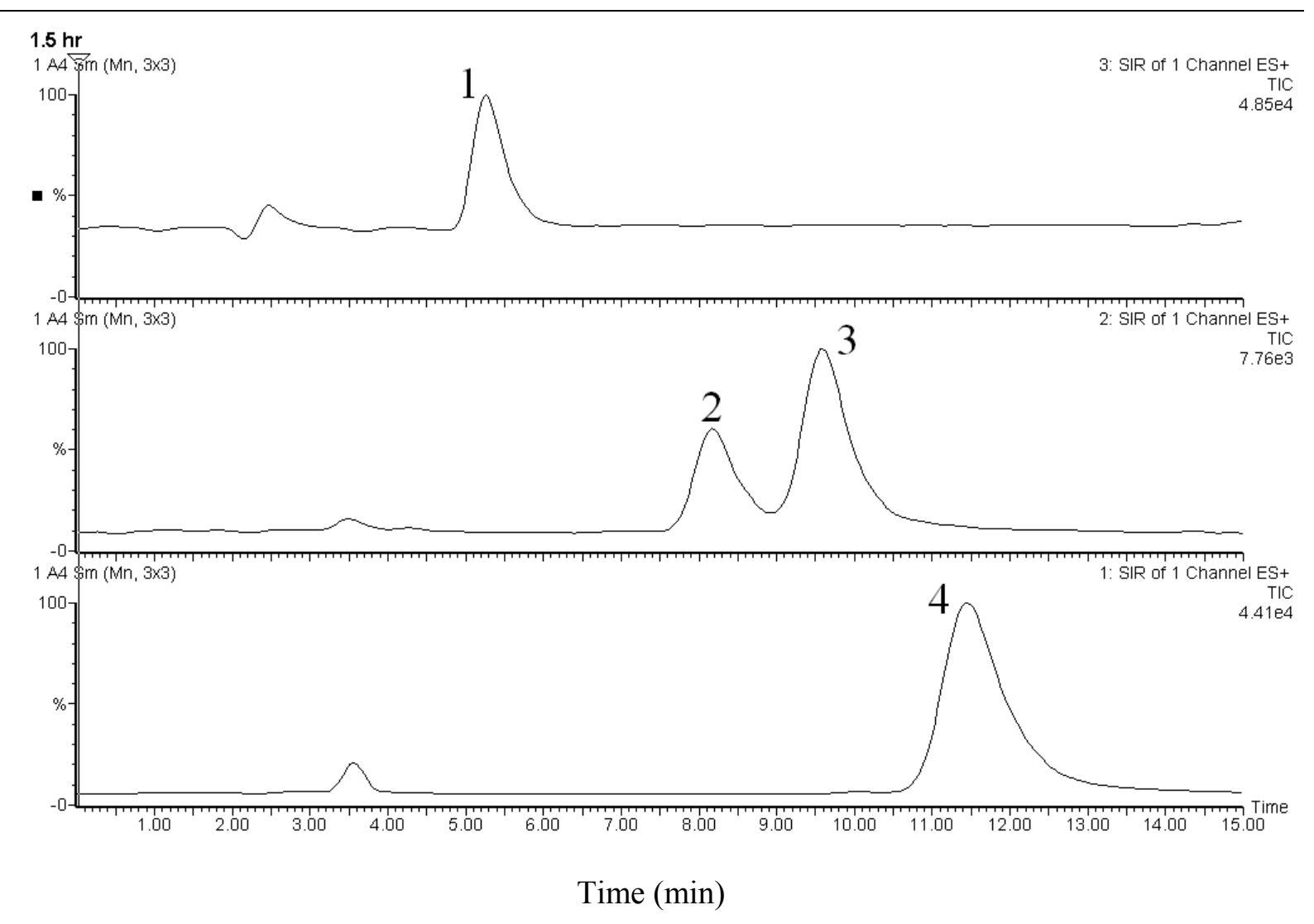

Figure 3. Chromatograms of extracted plasma sample obtained at $90 \mathrm{~min}$ after oral administration of the racemic cetirizine $(0.5 \mathrm{mg} / \mathrm{kg}$, or equivalent to $0.25 \mathrm{mg} / \mathrm{kg}$ of levocetirizine) and pseudoephedrine $(12 \mathrm{mg} / \mathrm{kg})$ in the dog. Peaks $1,2,3$ and 4 are pseudoephedrine, dextrocetirizine, levocetirizine and diazepam, respectively. Their retention times were identical to those of Figure 2.

\begin{tabular}{|c|c|c|c|}
\hline Nominal concentration $(\mathrm{ng} / \mathrm{mL})$ & Concentration found $(\mathrm{ng} / \mathrm{mL})$ & R.S.D. $(\%)$ & Recovery $(\%)$ \\
\hline \multicolumn{4}{|l|}{ Levocetirizine } \\
\hline \multicolumn{4}{|l|}{ Within-run $(n=6)$} \\
\hline 1 & 1.1 & 15.5 & 111.9 \\
\hline 3 & 3.2 & 7.3 & 107.4 \\
\hline 100 & 98.5 & 9.6 & 98.5 \\
\hline 160 & 155.6 & 6.6 & 97.2 \\
\hline \multicolumn{4}{|l|}{ Between-run $(n=6)$} \\
\hline 1 & 1.2 & 15.0 & 117.8 \\
\hline 3 & 3.3 & 11.6 & 111.2 \\
\hline 100 & 98.9 & 10.0 & 98.9 \\
\hline 160 & 163.9 & 5.9 & 102.4 \\
\hline \multicolumn{4}{|l|}{ Pseudoephedrine } \\
\hline \multicolumn{4}{|l|}{ Within-run $(n=6)$} \\
\hline 5 & 5.7 & 16.0 & 117.2 \\
\hline 15 & 15.2 & 9.6 & 101.4 \\
\hline 500 & 518.3 & 8.5 & 103.7 \\
\hline 800 & 792.7 & 6.5 & 99.1 \\
\hline \multicolumn{4}{|l|}{ Between-run $(n=6)$} \\
\hline 5 & 5.9 & 17.9 & 117.1 \\
\hline 15 & 15.9 & 6.6 & 106.0 \\
\hline 500 & 486.3 & 9.4 & 97.3 \\
\hline 800 & 795.1 & 7.7 & 99.4 \\
\hline
\end{tabular}




\section{Extraction efficiency and matrix effects}

The mean extraction efficiency averaged $80.5 \pm$ $6.7 \%$ for pseudoephedrine, $87.0 \pm 5.8 \%$ for levocetirizine and $91.3 \pm 5.5 \%$ for diazepam (Table 2). The extraction efficiency was within the acceptable range. The post-column infusion system was used to assess matrix effects. There was no significant ion suppression or enhancement at the region for retention time of levocetirizine, pseudoephedrine and diazepam. It is noted that no endogenous substances significantly interfered with the ionization of the analytes.

\section{Lower limit of quantification}

The LLOQ for levocetirizine was $1 \mathrm{ng} / \mathrm{mL}$, and the precision $(n=6)$ at this concentration was $15.5 \%$. The LLOQ for pseudoephedrine in dog plasma was $5 \mathrm{ng} / \mathrm{mL}$, and the precision $(n=6)$ at this concentration was $17.9 \%$.

\section{Stability}

Stock solutions of pseudoephedrine, levocetirizine and the internal standard were stable at $-80^{\circ} \mathrm{C}$ for 3 months. The stability of the working solution was good at both 4 and $20^{\circ} \mathrm{C}$ for at least a week. QC samples were stable at $-80^{\circ} \mathrm{C}$ for 3 months. No significant decreases in the concentrations of pseudoephedrine and levocetirizine in plasma were observed during the three freeze-thaw cycles (Table 3). In plasma samples stored at $4^{\circ} \mathrm{C}$ and $20^{\circ} \mathrm{C}$ during $24 \mathrm{~h}$, no significant losses were detected for levocetirizine and pseudoephedrine. The percentages of deviation of calculated versus theoretical concentrations at $4^{\circ} \mathrm{C}$ were less than $4.1 \%$ for levocetirizine determined at 3 and 160 $\mathrm{ng} / \mathrm{mL}$ and less than $4.7 \%$ for pseudoephedrine determined at 15 and $800 \mathrm{ng} / \mathrm{mL}$. The deviation of calculated versus theoretical concentrations at $20^{\circ} \mathrm{C}$ was less than $5.5 \%$ for levocetirizine and less than $5.1 \%$ for pseudoephedrine.

\section{Pharmacokinetic study}

The mean plasma concentration-time profiles of levocetirizine and pseudoephedrine found in dogs after oral administration of the racemic cetirizine $(0.5 \mathrm{mg} / \mathrm{kg}$, or $0.25 \mathrm{mg} / \mathrm{kg}$ as levocetirizine) and pseudoephedrine $(12 \mathrm{mg} / \mathrm{kg})$ are shown in Figure 4. The pharmacokinetic parameter values of the maximum concentration $\left(\mathrm{C}_{\max }\right)$, time to the maximum concentration $\left(\mathrm{T}_{\max }\right)$ and area under the curve (AUC) are shown in Table 4.

\section{DISCUSSION}

This study reports the development of a LC-MS assay method for the simultaneous determination of levocetirizine and pseudoephedrine in dog plasma in the presence of dextrocetirizine. The total run time of this assay $(<15 \mathrm{~min})$ is shorter than those of the previously reported assays (approximately $40 \mathrm{~min}$ ) $(3,16)$. Dextrocetirizine could not be obtained in this study, but the peak eluting at approximately 8.3 min (Figs. $2-3$ ) was not detected either after oral administration of levocetirizine $(0.25 \mathrm{mg} / \mathrm{kg})$ in dogs, or in the blank plasma spiked with levocetirizine (200 $\mathrm{ng} / \mathrm{mL})$, pseudoephedrine $(1000 \mathrm{ng} / \mathrm{mL})$ and diazepam (data not shown). Therefore, the corresponding peak was regarded as the dextrocetirizine peak.

The LLOQ of this assay $(1 \mathrm{ng} / \mathrm{mL})$ is significantly improved compared with those of previously reported HPLC methods, e.g., 2.5 $\mu \mathrm{g} / \mathrm{mL}$ for $0.1 \mathrm{~mL}$ of rat plasma (2), $400 \mathrm{ng} / \mathrm{mL}$ for $5 \mathrm{~mL}$ of human urine (16), and $20 \mathrm{ng} / \mathrm{mL}$ for 2 $\mathrm{mL}$ of human plasma (3). The previously reported LC-MS/MS method allows a sensitive measurement of levocetirizine (LLOQ $0.5 \mathrm{ng} / \mathrm{mL}$ for $0.3 \mathrm{~mL}$ of human plasma) (5), but this assay has disadvantages including time-consuming twostep sample extraction procedures and normal phase chromatographic separation using organic solvents.

The oral pharmacokinetic studies of levocetirizine, racemic cetirizine or pseudoephedrine in dogs have not been found in the literature to be compared with this study. In this study, however, the peak areas of levocetirizine were larger than those of dextrocetirizine after oral administration of the racemic cetirizine (Figure 3), while the peak intensities of levocetirizine and dextrocetirizine were almost the same in blank plasma spiked with cetirizine (Figure 2). Although plasma dextrocetirizine concentrations were not determined due to the unavailability of the standard material, these concentrations appear to be lower than levocetirizine concentrations after oral administration of the racemic cetirizine in this study. This is consistent with the previous finding that the clearance of levocetirizine is lower than that of dextrocetirizine in human (1). 


\begin{tabular}{cccccccc}
\hline \multicolumn{3}{c}{ Table 2. Extraction recovery (\%) for levocetirizine, pseudoephedrine and diazepam (mean \pm S.D.) $(n=3)}$. \\
\hline Recovery & $\begin{array}{c}\text { Levocetirizine } \\
(\mathrm{ng} / \mathrm{mL})\end{array}$ & \multicolumn{3}{c}{$\begin{array}{c}\text { Pseudoephedrine } \\
(\mathrm{ng} / \mathrm{mL})\end{array}$} & $\begin{array}{c}\text { Diazepam } \\
(\mathrm{ng} / \mathrm{mL})\end{array}$ \\
\hline$(\%)$ & 3 & 100 & 160 & 15 & 500 & 800 & 2000 \\
Mean \pm & 86.8 & 88.5 & 85.7 & 79.0 & 77.7 & 84.7 & 91.3 \\
S.D. & 6.0 & 6.5 & 7.1 & 5.9 & 6.1 & 8.1 & 5.5 \\
\hline
\end{tabular}

\begin{tabular}{lcccc}
\hline \multicolumn{3}{l}{ Table 3. Long-term and freeze-thaw stability data for levocetirizine and pseudoephedrine. } \\
\hline $\begin{array}{c}\text { Concentration } \\
(\mathrm{ng} / \mathrm{mL})\end{array}$ & $\begin{array}{c}\text { Long-term stability } \\
\text { Storage period } \\
\text { \% Remaining } \\
\text { after storage }\end{array}$ & $\begin{array}{c}\text { Freeze-thaw stability } \\
\text { \% Remaining after freeze- } \\
\text { thaw cycles }\end{array}$ \\
\hline $\begin{array}{l}\text { Levocetirizine } \\
3\end{array}$ & 1 & $98.9 \pm 4.3$ & 1 & $102.0 \pm 4.7$ \\
& 2 & $97.5 \pm 3.1$ & 2 & $98.5 \pm 5.1$ \\
160 & 3 & $96.7 \pm 3.2$ & 3 & $93.2 \pm 6.3$ \\
& 1 & $102.5 \pm 4.1$ & 1 & $99.7 \pm 4.1$ \\
Pseudoephedrine & 2 & $98.1 \pm 3.3$ & 2 & $95.3 \pm 3.2$ \\
15 & 3 & $95.7 \pm 4.9$ & 3 & $94.1 \pm 5.1$ \\
& 1 & $103.1 \pm 5.1$ & 1 & $99.7 \pm 5.8$ \\
800 & 2 & $99.1 \pm 3.8$ & 2 & $97.1 \pm 3.6$ \\
& 3 & $98.9 \pm 3.2$ & 3 & $101.0 \pm 2.8$ \\
& 1 & $98.9 \pm 3.4$ & 1 & $98.1 \pm 4.1$ \\
& 2 & $97.1 \pm 4.2$ & 2 & $95.5 \pm 4.3$ \\
\hline
\end{tabular}

${ }^{a}$ Calculated as the percentage of the initial concentration and expressed as mean \pm S.D. $(n=3)$.

Table 4. Pharmacokinetic parameter values found in $\operatorname{dogs}(\mathrm{n}=6)$ after oral administration of cetirizine ( $0.5 \mathrm{mg} / \mathrm{kg}$, or equivalent to $0.25 \mathrm{mg} / \mathrm{kg}$ ) and pseudoephedrine $(12 \mathrm{mg} / \mathrm{kg})$.

\begin{tabular}{ccc}
\hline Parameters & Levocetirizine & Pseudoephedrine \\
$\mathrm{C}_{\max }(\mathrm{ng} / \mathrm{mL})$ & $(0.25 \mathrm{mg} / \mathrm{kg})$ & $(12 \mathrm{mg} / \mathrm{kg})$ \\
$\mathrm{T}_{\max }(\mathrm{hr})$ & $74.4 \pm 11.7$ & $396.5 \pm 106.2$ \\
$\mathrm{AUC}(\mathrm{ng} \cdot \mathrm{hr} / \mathrm{mL})$ & $3.6 \pm 1.6$ & $5.3 \pm 1.4$ \\
$\mathrm{t}_{1 / 2}(\mathrm{hr})$ & $791.6 \pm 188.0$ & $4437.2 \pm 1278.2$ \\
\hline
\end{tabular}

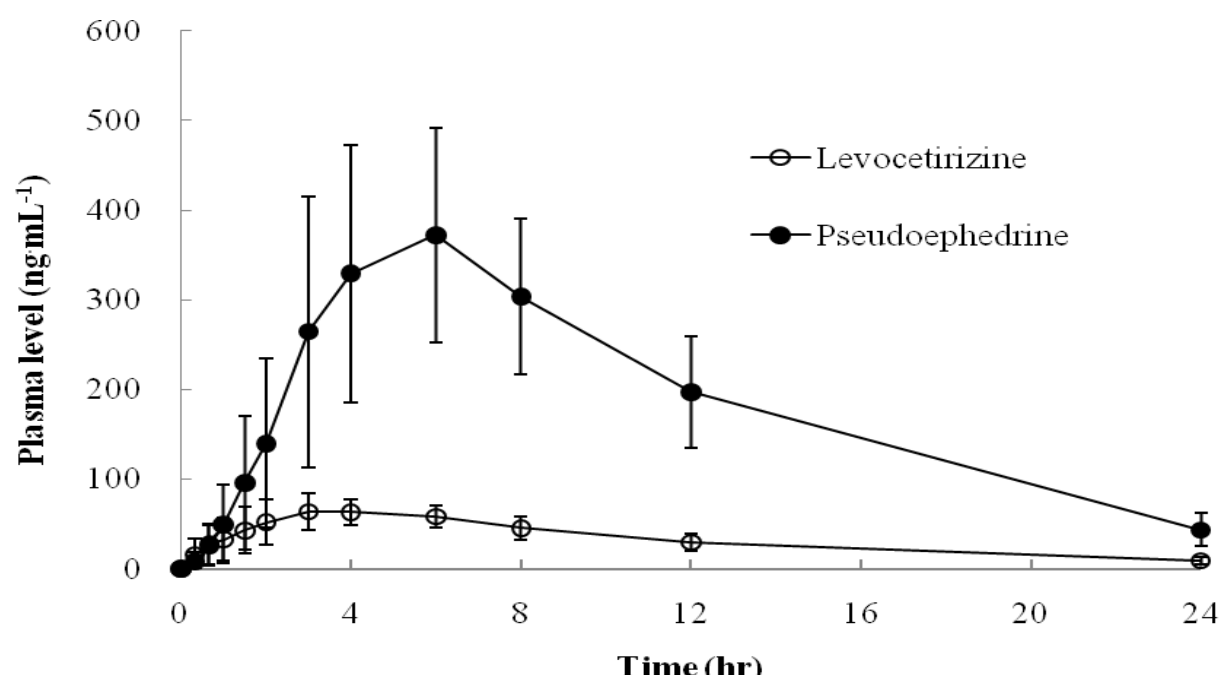

Figure 4. Plasma concentration-time profiles of levocetirizine and pseudoephedrine after oral co-administration of the racemic cetirizine $(0.5 \mathrm{mg} / \mathrm{kg}$, or equivalent to $0.25 \mathrm{mg} / \mathrm{kg}$ of levocetirizine) and pseudoephedrine $(12 \mathrm{mg} / \mathrm{kg})$ to beagle $\operatorname{dogs}(\mathrm{n}=6)$. 


\section{CONCLUSIONS}

In summary, a rapid and sensitive LC-MS method capable of enantioselective separation of cetirizine was developed for the simultaneous quantitation of levocetirizine and pseudoephedrine concentrations in dog plasma. This method is simple, reproducible and specific and allows for the separation of pseudoephedrine, levocetirizine and diazepam from other components in plasma samples, including dextrocetirizine. To date, it is the first achiral and chiral method allowing for the simultaneous determination of pseudoephedrine and levocetirizine concentrations in dog plasma in the presence of dextrocetirizine.

\section{REFERENCES}

1. Tillement JP, Testa B, Brée F. Compared pharmacological characteristics in humans of racemic cetirizine and levocetirizine, two histamine H1-receptor antagonists. Biochem Pharmacol, 2003;66:1123-1126.

2. S Choi SO, Lee SH, Kong HS, Kim EJ, Choo HY. Stereoselective determination of cetirizine and studies on pharmacokinetics in rat plasma. J Chromatogr B Biomed Sci Appl, 2000; 744:201206.

3. Baltes E, Coupez R, Giezek H, Voss G, Meyerhoff C, Strolin Benedetti M. Absorption and disposition of levocetirizine, the eutomer of cetirizine, administered alone or as cetirizine to healthy volunteers. Fundam Clin Pharmacol, 2001;15:26977.

4. Toribio L, del Nozal MJ, Bernal JL, Cristofol C, Alonso C. Study of the enantiomeric separation of oxfendazole and cetirizine using subcritical fluid chromatography on an amylose-based column. J Chromatogr A, 2006;1121:268-273.

5. S.W. Kang, H.J. Jang, V.S. Moore, J.Y. Park, K.A. Kim, J.R. Youm, S.B. Han, J. Chromatogr. B 878 (2010) 3351-3357.

6. Nieder M, Jaeger H. Sensitive quantification of pseudoephedrine in human plasma and urine by high-performance liquid chromatography. J Chromatogr, 1988;424:73-82.

7. Herráez-Hernández R, Campíns-Falcó P. Automated trace enrichment for screening and/or determination of primary, secondary and tertiary amphetamines in biological samples by liquid chromatography. Analyst, 1999;124:239-244.
8. Macek J, Ptáek P, Klíma J. Rapid determination of pseudoephedrine in human plasma by highperformance liquid chromatography. J Chromatogr B Analyt Technol Biomed Life Sci, 2002;766:289294.

9. Lo LY, Land G, Bye A. Sensitive assay for pseudoephedrine and its metabolite, norpseudoephedrine in plasma and urine using gas-liquid chromatography with electron-capture detection. J Chromatogr, 1981;222:297-302.

10. Gunn J, Kriger S, Terrell AR. Identification and quantitation of amphetamine, methamphetamine, MDMA, pseudoephedrine, and ephedrine in blood, plasma, and serum using gas chromatographymass spectrometry (GC/MS). Methods Mol Biol, 2010;603:37-43.

11. Chen X, Zhang Y, Zhong D. Simultaneous determination of chlorpheniramine and pseudoephedrine in human plasma by liquid chromatography-tandem mass spectrometry. Biomed Chromatogr, 2004;18:248-53.

12. Sun J, Wang G, Wang W, Zhao S, Gu Y, Zhang J, Huang M, Shao F, Li H, Zhang Q, Xie H. Simultaneous determination of loratadine and pseudoephedrine sulfate in human plasma by liquid chromatography-electrospray mass spectrometry for pharmacokinetic studies. J Pharm Biomed Anal, 2005;39:217-24.

13. Ma M, Feng F, Sheng Y, Cui S, Liu H. Development and evaluation of an efficient HPLC/MS/MS method for the simultaneous determination of pseudoephedrine and cetirizine in human plasma: application to phase-I pharmacokinetic study. J Chromatogr B Analyt Technol Biomed Life Sci, 2007;846:105-111.

14. Choi HG, Jun HW, Kim DD, Sah H, Yoo BK, Yong CS. Simultaneous determination of cefatrizine and clavulanic acid in dog plasma by HPLC. J Pharm Biomed Anal, 2004;35:221-231.

15. Van Eeckhaut A, Lanckmans K, Sarre S, Smolders I, Michotte Y. Validation of bioanalytical LCMS/MS assays: evaluation of matrix effects. J Chromatogr B Analyt Technol Biomed Life Sci, 2009;877:2198-2207.

16. Choi SO, Lee SH, Kong HS, Kim EJ, Choo HY. Enantioselective determination of cetirizine in human urine by HPLC. Arch Pharm Res, 2000;23:178-181. 